JURÍČKOVÁ, L., IVANOVÁ, K., FILKA, J. 2014. Opatrovnictví osob s duševní poruchou. 1. vyd. Praha: Grada, 2014. ISBN 978-80-247-4786-6.

Kniha Opatrovnictví osob s duševní poruchou jako první uceleně popisuje praktický výkon činností opatrovníka a reflektuje změnu paradigmatu instituce opatrovnictví. Autorka PhDr. Lubica Juríčková, Ph.D. působí jako zástupkyně přednostky Ústavu sociálního lékařství a zdravotní politiky na Lékařské fakultě Univerzity Palackého v Olomouci. Profesně se zaměřuje na andragogiku, zdravotnický management, veřejné zdravotnictví a lidské zdroje ve zdravotnictví. Problematikou opatrovnictví se dlouhodobě zabývá. Autorka doc. PhDr. Kateřina Ivanová, Ph.D. je přednostkou Ústavu sociálního lékařství a zdravotní politiky na Lékařské fakultě Univerzity Palackého v Olomouci. Její profesní zaměření je sociologie, sociální lékařství a veřejné zdravotnictví. V roce 2003 organizovala konferenci o sociálně právním opatrovnictví dospělých osob. Autor PhDr. ThLic. Ing. Jaroslav Filka působí na Cyrilometodějské teologické fakultě, Katedře pastorální a spirituální teologie, Univerzity Palackého v Olomouci. Specializuje se na studium křestanské spirituality. Zabývá se problematikou tradičních forem zbožnosti. Věnuje se rovněž vybraným otázkám z ikonografie a nové evangelizace.

Autoři problematiku opatrovnictví osob s duševním onemocněním zpracovali komplexně v rozsahu 160 stran v pěti kapitolách. V první kapitole je obecně popsán fenomén opatrovnictví v podobě institucionalizace opatrovnictví. Podkapitoly vymezují východiska pro institucionalizaci opatrovnictví a současnou podobu institucionalizace opatrovnictví. Stručně a přehledně jsou v první kapitole popsány právní dokumenty pro podporu osob s duševní poruchou.

V druhé kapitole autoři hodnotí zdravotně-sociální kontext opatrovnictví. Zde jsou vymezeny pojmy duševní zdraví, normalita duševního zdraví. Součástí je vymezení klinické formy duševních poruch. Zdravotní kontext uvádí čtenáře do oblasti psychiatrické péče. Popsána je péče v psychiatrických ambulancích a její vývoj, a péče v lůžkových zařízeních. Autoři se zabývají problematikou sociální péče o osoby s duševní poruchou. Statistika počtu nemocných a počtu zařízení, která poskytují zdravotnickou a sociální péči je bohatě popsána a umožňuje čtenáři si vytvořit jasný přehled.
Třetí kapitola se zabývá systémem opatrovnictví $\mathrm{v}$ praxi. Autoři velmi výstižně popisují proces řízení o způsobilosti k právním úkonům a schéma opatrovnictví. Kapitolu doplňují přehledné tabulky s výsledky výzkumu odborníků z Univerzity Palackého, kteří zjištovali údaje o opatrovancích $\mathrm{z}$ hlediska věku, pohlaví, psychiatrických diagnóz a rozhodnutí soudů. Podobně jsou zde znázorněny a popsány výsledky zmíněného výzkumu, tentokrát v kategorii opatrovníků.

Ve čtvrté kapitole nazvané „Výkon veřejného opatrovnictví v praxi“ jsou uvedeny výsledky navazujícího výzkumu z roku 2011, který uceleně popisuje nejčastěji vykonávané činnosti opatrovníků a identifikuje problémy při výkonu opatrovnické funkce. Součástí kapitoly jsou praktické rady veřejných opatrovníků, zahrnující řadu doporučení při jednání a komunikaci ve vztahu opatrovníka k opatrovanci. Autoři upozorňují na nedostatečnou komunikaci opatrovníků s opatrovanci. Jak je autory zmíněno, klesá počet rodin ochotných a schopných se o člena rodiny postarat, a to vlivem měnící se socioekonomické situace. Problémy autoři spatřují i v oblasti právního vymezení opatrovnictví, které je nedostatečné.

V poslední kapitole poukazují autoři na prognózu a perspektivy vývoje opatrovnictví. Mnohé úvahy jsou cenné pro zlepšení úrovně institutu opatrovnictví. Úvahy zahrnují návrhy na změny systému péče o osobu s duševní poruchou, reformu psychiatrické péče a transformaci sociálních služeb. Autoři ve svých úvahách reagují na demografickou podmíněnost vývoje opatrovnictví. Na závěr kapitoly je zařazeno zakotvení výkonu opatrovnictví dle nového ObčZ, který vymezuje jasná pravidla pro výkon opatrovnictví.

Kniha je velmi přehledně zpracovaná, poskytuje teoretický a zejména praktický pohled na opatrovnictví osob s duševní poruchou. Popisné a grafické zpracování výsledků uvedených výzkumů a přehled v právním zakotvení institutu opatrovnictví, umožňuje čtenáři získat ucelený přehled o tomto tématu. Knihu lze doporučit zaměstnancům veřejné správy, pracovníkům výkonné moci, zdravotnickým pracovníkům, sociální pracovníkům, opatrovníkům a dalším zájemcům o opatrovnictví osob s duševní poruchou. 
Doporučila bych v knize blíže popsat problematiku opatrovnictví v sociálních službách, která je velmi pestrá a nabízí mnoho podnětů k hodnocení opatrovnictví. V publikaci postrádám popis institutu opatrovnictví v psychologickém kontextu, chybí hlubší analýza kvality vztahů opatrovníků s opatrovanci. V príloze „Výzkum opatrovnictví Univerzity Palackého (2009-2011)“, není uveden detailnější popis prrípravy a realizace výzkumu, pro př́padné další využití v teorii a praxi.

Publikace předkládá čtenářům téma opatrovnictví, které nebylo dosud takto uceleně, jasně a přehledně zpracováno. Jedinečné je propojení uvedených teoretických koncepcí s praktickým pohledem na výkon funkce opatrovníka.

Použitá literatura nabízí přehled zdrojů, které mohou být pro čtenáře inspirací. Základní orientaci v problematice zajištuje přehled termínů k tématu, uvedený na konci knihy.

\section{AUTOR RECENZE}

Mgr. Radka Kozáková

Ústav společenských a humanitních věd

Fakulta zdravotnických věd

Univerzity Palackého v Olomouci

Tř. Svobody 8

CZ-771 11 OLOMOUC

radka.kozakova@upol.cz ecirizaros

Lubica Juričková, Katefina Ivanovà,

Jaroslav Filka

\section{Opatrovnictví osob s duševní poruchou}

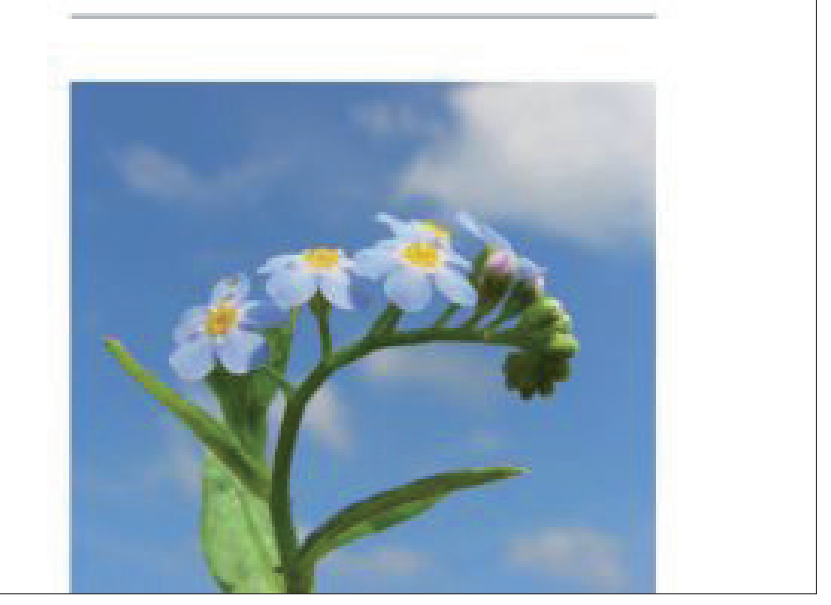

Zdroj obrázku: http://www.grada.cz/php/viewpic.php?foto=../ obalky_upr/747866.jpg\&w=270\&h=390 (cit. 2014-04-14) 